\title{
RELIGION, VIOLENCE AND THE ISLAMIC TRADITION OF NONVIOLENCE
}

\author{
S. AYŞE KADAYIFÇI-ORELLANA
}

\begin{abstract}
Religion is often viewed as a propellant of conflict and violence in international relations and conflict resolution studies. The relationship between violence and religion in general, and Islam in particular, became a central concern for scholars and policy makers especially after the September 11, 2001 attacks on the World Trade Center and the Pentagon. However, history provides that religion has also been a source and inspiration for nonviolent resistance and peace-building. This paper explores the relationship between religion and violence and attempts to understand how religious traditions can be employed for peace-building and nonviolent resistance. To support this idea, the paper introduces the Islamic tradition of nonviolence and provides two examples of how this tradition was employed successfully.
\end{abstract}

\section{KEYWORDS}

Islam, violence, nonviolence, conflict resolution and Islam, Islam and war, Islam and peace 


\section{INTRODUCTION}

The end of the Cold War was greeted with much optimism around the world, as the threat of a nuclear war was considered to be cast off. Many envisioned a new era, a new order, where liberty, democracy, and peace would reign. However, such hopes were shattered quickly as new types of conflicts proliferated and threatened the global system, and many old ones, (such as the Israeli-Palestinian, India-Pakistan, Northern Ireland, etc.) continued to be intractable. Most of these post-Cold War conflicts involve communities with different cultures and religious traditions. These communities have been traumatized with the impact of colonization and imperialism, and are lagging behind the West in terms of material, technical and scientific achievements. Many of these societies suffer from extreme poverty and economic deprivation as well as the pressure of the globalization. In many of these post-Cold War conflicts, religion, as one of the central identifying characteristics of the communities, is often used to justify war and violence, as well as to construct negative enemy images, even though main reasons of the conflict may not be religious. Consequently, religion has come to be seen as a propellant of conflict and violence.

The relationship between violence and religion in general, and Islam in particular, became a central concern for scholars and politicians especially after the heinous attacks on the Twin Towers and the Pentagon on September 11, 2001. Others, such as Bali bombings in 2002 and Istanbul bombings in November 2003, followed these attacks. Declaring Jihad, the Islamic extremist group, al-Qaeda, that claimed responsibility for these attacks, asserted that these attacks were justified by Islam. In the meanwhile, other Islamic groups, such as Hamas and Islamic Jihad in the West Bank and Gaza, have been employing suicide attacks on Israeli civilians since early 1990s. They too, argue that such acts are legitimate according to Islam. These horrific acts of Islamic groups and their claims that these acts are legitimate according to the Islamic tradition have significantly contributed to the image of Islam as a violent religion. As a result, Islam and violence have come to be perceived almost synonym in the minds of many non-Muslims. 
Nevertheless, the religious traditions that are used to justify violence and war, have also been sources of inspiration for nonviolent active resistance and peace-building. Based on this observation, this article explores the relationship between religion and violence and argues that religion can also be a positive force to establish justice, and peace through nonviolent activism. In this line, this article specifically looks at the tradition of nonviolence embedded in the Islamic discourse.

Given the current representation of Islam, Islamic tradition of nonviolence might seem as an oxymoron to the reader. Indeed, even the majority of Muslims are unaware of the tradition of nonviolence embedded in Islam. However, an inquiry into the Islamic scholarship on peace would provide plenty of examples to the contrary. ${ }^{1}$ In fact, nonviolence has been an integral aspect of Islamic discourse on peace since the time of the Prophet Mohammed and has been employed in

${ }^{1}$ See Abu-Nimer, Mohammed, Nonviolence and Peacebuilding in Islam (Florida: University Press of Florida, 2003); Kadayıfçı-Orellana, S. Ayşe, Standing on an Isthmus: Islamic Narratives of War and Peace in Palestine, Doctoral Dissertation, (Washington D.C.: School of International Service, American University at Washington D.C., 2002); Khan, Inamullah, "Nuclear War and the Defense of Peace: The Muslim View," International Peace Research Newsletter, Vol. 23, No. 2 (April 1985), 9-11; Khan, Maulana Wahiduddin, "Non-Violence and Islam", paper prepared for the Symposium: Islam and Peace in the $21^{\text {st }}$ Century, Washington D.C. (February 6-7, 1998); Said, Abdul Aziz, Nathan C. Funk and S. Ayşe Kadayıfçı, eds., Peace and Conflict Resolution in Islam: Precept and Practice (New York: University Press of America, 2001); Said, Abdul Aziz, Nathan C. Funk and S. Ayşe Kadayıfçı, "Islamic Approaches to Conflict Resolution and Peace", The Emirates Occasional Papers, No. 48 (Abu Dhabi: The Emirates Center for Strategic Studies and Research, 2002); Sa'id Jawdat, The Doctrine of the First Son of Adam: The Problem of Violence in Islamic Practice, $5^{\text {th }}$ edition (Damascus: Dar al Fikr, 1993); Sa'id, Jawdat, "Peace-or Nonviolence- in History and with the Prophets", paper written for Conference on Islamic Values for Change, trans. by Dr. Abduhu Hammud al-Sharif, revised with notes by Dr. Karim Crow (Syria: Bi'r Ajam, Qunaytra, April 3, 1997); Sa'id Jawdat, "Law, Religion and the Prophetic Method of Social Change", Journal of Law and Religion, Vol. 15 No.1 and 2 (2000-2001), 83-149; Paige, Glenn D., Chaiwat Satha-Anand, Sarah Gilliatt, eds. Islam and Nonviolence (Center for Global Nonviolence, 2001). 
various occasions and not without success. Therefore, this article also presents religious intellectual debates concerning the legitimacy of nonviolence as an Islamic approach and two examples of successful nonviolent movements rooted within the Islamic tradition.

\section{USE AND ABUSE OF RELIGION}

Violent conflict is a result of human actions and decision, and is co-constructed through the actions of individuals situated in relation to the discursive and institutional continuities that enable the occurrence of war and render it a legitimate human behavior. ${ }^{2}$ Individuals give meaning to their world and social and discursive structures draw the boundaries of what can or cannot be said. ${ }^{3}$ These discursive and social structures, such as religious, ideological and cultural traditions can be used either to justify violence, dehumanization of the enemy, and war, or can be used to promote reconciliation, peace-building, and constructive relationships.

Religion, as a system of beliefs and practices relating to the sacred, and uniting its adherents in a community, has a powerful hold on people's way of thinking, acting and perception of interests. ${ }^{4}$ Religious feelings can mobilize people faster than any other element of their identity. The moral and spiritual forces of religion encourage people to act and change. ${ }^{5}$ Rituals are powerful means of communication, in which followers of a religion connect to their spiritual sources and observe their values and beliefs. "When a moral message serves to mobilize mass action, or when the moral messenger backs its words with effective leadership of its own, the religious actor can become a significant catalyst for change."

\footnotetext{
${ }^{2}$ Vivienne Jabri, Discourses On Violence- Conflict Analysis Reconsidered (Manchester University Press, 1996:4).

${ }^{3}$ Kadayıfçı-Orellana, op. cit. 2002, 11.

${ }^{4}$ Ibid., 82.

${ }^{5}$ Abu Nimer, op. cit. 2003, 17.

${ }^{6}$ Ibid., 18.

${ }^{7}$ Sampson, Cynthia "Religion and Peace Building" in Peacemaking in International Conflict: Methods and Techniques, W. Zartman and L.
} 
Religion offers a language and symbolism through which human beings interpret reality as well as get comfort for trauma and injuries. ${ }^{8}$ However, texts, and in particular religious texts are often filled with ambiguities, contradicting statements, and are written down in a distant time, usually in a language that is different from the ones used by the current communities. ${ }^{9}$ Although one may believe that religious texts, such as the Quran, is the direct word of God, it still has to go though human interpretation. Historical, political, social, economic and cultural contexts of the interpreting agent effects the way religious texts are understood. ${ }^{10}$

According to Marc Gopin, the way sacred texts are used to foster peace or promote violence and destruction:

...seems to depend on the complex ways in which the psychological and sociological circumstances and the economic and cultural constructs of a particular group interact with the ceaseless human drive to hermeneutically develop religious meaning systems, texts, rituals, symbols, and laws."

Especially under extreme conditions, such as at times of war, religious texts are interpreted through deep fears and concerns. At such times various verses, ideas, or spiritual images may meet cognitive and emotional needs of the individual. ${ }^{12}$ Accordingly, the turbulent relations with the "enemy" impact the way texts are understood. Various tales, sagas, and myths are selected to support interpretation of the religious tradition that legitimize war, and construct negative enemy images.

Rasmussen, eds. (Washington D.C.: United States Institute of Peace Press. Washington DC., 1997), 281.

${ }^{8}$ Kadayıfçı-Orellana, op. cit., 2002: 88.

${ }^{9}$ Idem.

${ }^{10}$ Idem.

"Gopin, Marc, Between Eden and Armageddon: The Future of World Religions, Violence, and Peacemaking. (Oxford University Press, 2000), 11.

${ }^{12}$ Ibid., 17. 
Moreover, religious actors simplify religious myths, dehistoricize religious texts, and construct a story in which all time, place, and difference are represented as meaningful parts of a divine project. With the aid of religious imagery and vocabulary, various sagas, myths and tales, with which the population is familiar, the past, the preset, and the future are linked in the minds of the population. Past wars and victories are interpreted from the perspective of the religious tradition, and are employed to recreate the history of the people. By locating these victories and wars in their collective memory religious and political actors engage the population into the politics of interpretation. By retelling these religious myths, sagas, and stories, they rewrite the history and shape the spaces (e.g. national homeland) and events (e.g. wars, victories, massacres, etc.) that constitute the basis of religious identity. Such stories create the imaginative boundaries that contain the identity of the people and influence self-interpretations and modes of exclusion and inclusion, ${ }^{13}$ self-other. These narratives reconfigure the imagination of the population within which the actions have meaning and thus become the contexts for action, such as defending the nation through war or suicide attacks. ${ }^{14}$

Many political leaders have used this unique power of religion for legitimating their policies and for mobilizing people towards their constructed ends. Although the main reasons and issues of a conflict may not be of religious character, religion plays a significant role at times of conflict where different religious systems encounter one another. In such cases, political leaders do not hesitate to resort to religious myths and sacred documents of their religion to justify their acts, and policies. By doing that they try to get the support of their communities and reinforce their power.

Use and abuse of religion to pursue political interests is not a novel practice. History presents numerous examples of abuse of religion to justify oppression, war and violence. ${ }^{15}$ The crusades, invasion of the Americas, and massacres of the indigenous peoples of

\footnotetext{
${ }^{13}$ See Kadayıfçı-Orellana, op. cit., 2002. Chapter VIII.

${ }^{14}$ Ibid.: 357

${ }^{15}$ See alšo Juergensmeyer, Mark Terror in the Mind of God: The Global Rise of Religious Violence (University of California Press, 2000).
} 
Americas were not only justified but also called for by religious authorities in Europe. More recently, in South Africa, religious beliefs, movements, leaders, especially the Afrikener neo-Calvinist interpretation of the Bible, played a central role in justifying the culture of Apartheid. In this case, Biblical notions of "chosennes", "the called," and the "Calvisinst idea of "predestination" was interpreted as justification for white supremacy. ${ }^{16}$

The use and abuse of religion to pursue political ends has been common in many of the post-Cold War conflicts as well, where religious identity plays a critical role in conflict dynamics. ${ }^{17}$ For example, religion was used to define the identities of the parties, and to justify violence and even gross violations of human rights during conflict in ex-Yugoslavia. Bosnian genicide was religiously motivated and justified on religious grounds by the Orthadox Serb nationalists. ${ }^{18}$

"Religious symbols ...myths of origin (pure Serb race), symbols of passion (Lazar [the Serbian King who died during the war against the Ottomans]), eschatological longings (resurrection of Lazar) were used by religious nationalists to create a reduplicating Milos Obilic (the assassin of Sultan Murat [the Ottoman Sultan that was killed during the war), avenging himself on the Christ killer, the race traitor, the alien, and ironically, the falsely accused "fundamentalist" next door.",19

Again, in that vein, suicide attacks are made possible through Hamas's interpretation of the martyrdom myth. ${ }^{20}$ The myth of martyrdom and the symbol of "the martyr" represent the utmost act of devotion to God in the Islamic tradition. As a powerful mythic

${ }^{16}$ Johnston, Douglas. "The Churches and Apartheid in South Africa," in Johnston and Sampson, eds. 1994, op. cit., 177-207: 184-185.

${ }^{17}$ See Abu Nimer, Mohammed. "Conflict Resolution, Culture, and Religion: Toward a Training Model of Interreligious Peacebuilding," Peace Research, (38:6, 2001), 685-704: 686.

${ }^{18}$ see Appleby, Scott, The Ambivalence of the Sacred: Religon, Violence and Reconciliation, (Rowman and Littlefield Publishers, Inc. 2000), 71.

${ }^{19}$ Sells, Michael, The Bridge Betrayed: Religions and Genocide in Bosnia, (Berkeley and Los Angeles: University of California Press, 1996):123 cited in ibid., 71.

${ }^{20}$ Kadayıfçı-Orellana, op. cit., 2002. 
construct, it gives meaning to not only one's existence, but more importantly, to one's death. ${ }^{21}$ Suicide, on the other hand, is one of the gravest sins according to Islam. Nevertheless, by reinterpreting the myth of martyrdom to include suicide attacks, Hamas leadership invokes the myth of ultimate form of sacrifice for God, for justice, and for one's own people. ${ }^{22}$ Such an interpretation endows Palestinians with the sense that they are not powerless or subservient, but can do something about the situation, and sap the Israeli morale, thus obliterate their psychology. Besides, by lending meaning and dignity to these actions in their minds, the myth of martyrdom provides comfort and paramount means of coping with suffering and loss, especially to the families of these individuals who undertake suicide actions.

Even Buddhism, known for its nonviolent principles, has been abused to justify violence. Sri Lankan history, regretfully, serves as a powerful example of this. Founded on the principles laid down by Ashoka, ${ }^{23}$ Sri Lanka has been the locale of one of the bloodiest conflicts in the $20^{\text {th }}$ century. During the conflict, the majority of Sri Lankans (who are Sinhalese Buddhists) have justified violence against the Tamils (18 percent of the population) using Buddhist chronicles of Ashoka that date back 2300 years. In their justification, they utilized the conversation that took place between eight Buddhist monks and King Arjuna, who, after another bloody war, had doubts about the moral value of his actions. According to the records, eight Buddhist monks reassures Arjuna that he, in fact, killed only one and a half soul (a monk and a novice), and the rest does not count as souls since they were not Buddhists, and that it was all right to kill the unbelievers. ${ }^{24}$ Therefore they justified massacring thousands of Tamils in the name

\footnotetext{
${ }^{21}$ Gopin, Marc, Holy War Holy Peace (Oxford University Press, 2002), 3132.

${ }^{22}$ For an analysis of Hamas' interpretation of jihad and use of martyrdom myth, see Kadayıfçı-Orellana, op. cit., 2002.

${ }^{23}$ The Indian King who, after a bloody battle that cost the lives of 100,000 people, turned to Buddhism and promoted nonviolence, ethnic and religious tolerance, vegetarianism, and the protection of the environment.

${ }^{24}$ see Rich, Bruce, To Uphold the World: The Message of Ashoka and Kautilya for the Twenty -First Century, forthcoming. See also Juergesmeyer, op. cit., 2000.
} 
of Buddhism. The modern revivalist Buddhist movement in Sri Lanka uses Buddhist history and its chronicles to justify violence against Tamils even today.

\section{RELIGION AS A SOURCE OF NONVIOLENCE AND PEACEMAKING}

The examples provided above are only a few of the conflicts, where religion has been used to justify violence and violations of human rights. However, this is not the whole story. "The dreadful record of religiously inspired violence and intolerance withstanding, history points a more complicated picture of religious identity. ${ }^{25} \mathrm{~A}$ picture, in which, the same religious traditions (which were used to justify violence) are the sources and inspiration for peace-building and nonviolent resistance.

In conflict situations, especially in intractable conflicts, transition from a war-like behavior to peace behavior is very hard, since the parties have invested significant resources to continue the conflict. The rival parties are under the influence of a history filled with resentment, dehumanization, anger, and rage. They usually have deep injuries and traumas as a result of the long-standing conflict. These factors contribute to the perpetuation of the negative images of the "enemy" thus, to the continuation of the conflict. However, for peace to be sustainable and lasting there is a need to change the negative perceptions of the "other" and to establish constructive relations between the communities. This requires justification for altering the negative mind frames concerning the "other," in addition to addressing the needs and interests of the parties. Religion, with its unique empowering and transforming power can be and has been employed successfully in this process.

Irrespective of how they are used or abused, most religious systems incorporate ideals of peace and promise peace as the outcome of their application. All religious traditions embody a wide variety of cultural and moral resources, which have configured the basis of personal and communal values that support nonviolence and prevent

\footnotetext{
${ }^{25}$ Scott Applyby, op. cit., 2000, 5.
} 
conflicts. Therefore, religion can play a constructive role in peacebuilding and reconciliation. Understanding the social, psychological, and cultural processes that play a significant role in the way that religious texts are understood, can significantly contribute towards that end.

There are various advantages in employing religious sources for building peace and nonviolence. First of all, religious involvement in nonviolent resistance and peacemaking initiatives can prepare and equip practitioners and diplomats for much more proactive roles in transforming the conflict. Gopin supports this view by stating that

"a close study of the sacred texts, traditions, symbols and myths that emerge in conflict situations may contribute to theoretical approaches by providing useful frame of reference for conflict resolution workshops, and interfaith dialogue groups, and by creating a bridge to the unique cultural expression of a particular conflict." 26

Moreover, religion can bring social, moral, and spiritual resources to the peace-building processes and nonviolent resistance. It can inflict a sense of engagement and commitment both to peace and to transforming a relationship of a missing dimension from the mechanical and instrumental conflict resolution models. ${ }^{27}$ Religious commitment can become a strong impetus for engaging in peacebuilding activities and bringing about social change. Engaging in religious peace-building can provide spiritual bases for transformation and compensate for mechanistic and instrumental conflict resolution models.

Additionally, religious traditions offer rich resources for resolving conflicts by advocating values such as repentance, forgiveness, justice and patience, among others. These values may be used to promote peace and nonviolence by emphasizing common humanity, and encourage co-existence. Religious rituals and values can be powerful tools in transforming hatred and animosity into cooperation. Furthermore, religious values, beliefs, customs, and institutions can assist healing deep social and personal injuries and

${ }^{26}$ Gopin, op. cit., 2000, 15.

${ }^{27}$ Appleby, op. cit., 2000, 5. 
traumas. Thus, religious traditions can also be rich resources for managing conflicts creatively, constructively, and nonviolently.

In that line, it is necessary for scholars and practitioners in conflict resolution and peace studies to understand and address how the population perceives, interprets, and remembers catastrophic events. They also have to understood the perceptions of injustice that lead the people to invoke texts that privilege violence over nonviolence, hatred over co-existence. Furthermore, it is necessary to identify myths that provide the basis for violence and analyze thoroughly how these myths are manipulated. Myths translate complex problems into manageable cognitive structures and make them comprehensible to the human mind. During conflict times myths become tools to make sense of human atrocities to "explain" the reasons and sources of the conflict to the people in a "clear" way. ${ }^{28}$ Therefore, negative myths (myths that justify hatred and violence) should be replaced by positive myths (myths that promote justice, peace, and reconciliation) and these positive myths must be supported with religious texts and images.

However, only legitimate religious actors and institutions have the capacity and the authority to interpret religious texts. In many of the conflict-ridden communities religious institutions represent a significant portion of the society and posses moral legitimacy, as well as the capacity to reach and mobilize the population. "Their daily contact with the masses, long record of charitable service, and reputation for integrity have earned the religious leaders and institutions a privileged status and an unparalleled legitimacy, especially in societies where religion enjoys a measure of independence from the state." ${ }^{29}$ For that reason, religious institutions and actors are in a unique position in their communities to become agents of change. It is, then, imperative that conflict resolution scholars and practitioners identify those religious authorities that are peace oriented. Only then, they could open channels through which these institutions and actors could connect to a wider network of peace-building initiatives across social, political, and economic spectrum.

\footnotetext{
${ }^{28}$ Kadayıfçı-Orellana, op. cit., 2002.

${ }^{29}$ Appleby, op. cit., 2000, 8.
} 
Religious actors can assume various roles in peacemaking. ${ }^{30}$ These include, but are not limited to, advocate, intermediary, observer and educator. ${ }^{31}$ For example, advocates may be catalysts for empowering weaker party, restructuring relationships, and transforming social structures. Intermediaries, on the other hand, may be effective in bringing parties together to resolve the conflict and transform the conflictual relationships. Observers may be effective in preventing violence and transforming the conflict dynamic. Finally, educators may work towards conflict transformation by reaching out to the community through sermons, training seminars, and other social activities. It is equally important, however, that conflict resolution scholars and practitioners develop training workshops that engage religious actors. Thus, religious peace-building becomes a major tool for training, empowering, and motivating religiously oriented people towards peace.

Using religious precepts and involvement of religious actors to resolve conflicts is not a new phenomenon. ${ }^{32}$ Religion, as a source that

${ }^{30}$ See Curle, Adam, Making Peace (London: Tavistock Publications, 1971) and Sampson, op. cit., 279-290.

${ }^{31}$ See Sampson, op. cit., 273-274.

${ }^{32}$ Some of the scholars who have been writing about the role of religion in peace building include, but are not limited to, Abu-Nimer, Mohammed, "Conflict Resolution, Culture, and Religion: Toward a Training Model of Interreligious Peacebuilding," Peace Research, vol. 38, no.6, 685-704 (2001); "Conflict Resolution in an Islamic Context: Some Conceptual Questions" in Peace and Change, (January, 1996) 22-40; Nonviolence and Peacebuilding in Islam, (University Press of America, 2002); Gopin, Marc, Confronting the Secular/Religious Conflict in Israel: Suggested Solutions", Religious Secular Relations in Israel: Social and Political Implications, Ephraim Ya'ar and Tamar Herman, ed. (Tel Aviv: Steinmetz Center for Peace Research, Tel Aviv University, and the Konrad Adenauer Foundation, 1998); "Religion, Violence, and Conflict Resolution" in Peace and Change, vol. 22. no.1, (January 1991) 1-31; "Forgiveness as an Element of Conflict Resolution in Religious Cultures: Walking the Tightrope of Reconciliation and Justice", Unpublished paper delivered Feb 19, at American University, 1999; Between Eden and Armageddon: The Future of World Religions, Violence, and Peacemaking, (Oxford University Press, 2000); Holy War Holy Peace (Oxford University Press, 2002); 
provides a language, a set of values, and institutions with which groups identify them selves, has been widely used by different communities to promote peace and reconciliation. ${ }^{33}$ Religious actors have been involved in peacemaking and reconciliation in many instances, and recently their efforts begun to grab the attention of scholars and other actors involved in conflict resolution. For example, Sampson observes "[g]rowing numbers of religious actors of many sorts - laypersons, individual religious leaders, denominational structures, ad hoc commissions and delegations, and interdenominational and multireligious bodies-have been involved in a range of peacebuilding efforts over the past couple of decades." ${ }^{34}$ As Abu-Nimer notes, "[f]raming the interventions within a religious context and deriving tools from a religious narrative have made possible for interveners to gain access and increase their potential impact on the parties."

Johnston, Douglas M., Religion and Conflict Resolution Paper presented at Fletcher Forum of World Affairs. (Winter/Spring 1996); Johnston, Douglas $\mathrm{M}$, and Cynthia Sampson, eds. Religion, The Missing Dimension of Statecraft, (New York: Oxford University Press, 1994); Lederach, J. P., Preparing for Peace: Conflict Transformation Across Cultures. (Syracuse: Syracuse University Press, 1995); Building Peace: Sustainable Reconciliation in Divided Society (United States Institute of Peace Press, 1997); Said, Abdul Aziz, Nathan C. Funk and S. Ayşe Kadayıfçı, eds. Peace and Conflict Resolution in Islam: Precept and Practice (New York: University Press of America, 2001); Sampson, Cynthia, "Religion and Peace Building" in Peacemaking in International Conflict: Methods and Techniques. W. Zartman and L. Rasmussen, eds. (Washington D.C.: United States Institute of Peace Press, Washington DC., 1997); Sampson and J. P. Lederach, eds. From the Ground Up: Mennonite Contributions to International Peacebuilding (New York: Oxford University Press, 2000); Smock, David R. Religious Perspectives on War (Washington DC.: United States Institute of Peace, 1992); Interfaith Dialogue and Peacebuilding (Washington D.C.: United States Institute of Peace Press, 2002).

${ }^{33}$ See specifically Johnson, D and C. Sampson, op. cit., 1994; Appleby, op. cit., 2000.

${ }^{34}$ Sampson, op. cit., $273-274$.

${ }^{35}$ Abu-Nimer, op. cit., 2001, 686. 


\section{NONVIOLENCE TRADITIONS}

In addition to conflict resolution and peace building traditions, many faith systems, such as Buddhism, Gandhi's understanding of Hinduism, Mennonites, Quakers, among others, incorporate traditions of nonviolence for social transformation and conflict resolution. ${ }^{36}$ Islam, too, incorporates the tradition of nonviolence. However, nonviolence is a frequently misunderstood concept, equated with inaction or keeping silence at times of oppression and threat of violence. Its critics argue that nonviolence fails to stop gross violations of human rights, unjust practices, and violence. Truth is that nonviolence is not passivity, nor inaction. On the contrary, nonviolence is a proactive method of resistance without resorting to violence. As Daniel L. Smith-Christopher states, "[n]onviolence includes not only the refusal to engage in lethal activities, but it also presumes a commitment to strive for conditions of fairness, justice, and respect in human relations." ${ }^{37}$

Etymologically, "non-violence' denotes rejection of use of violence to achieve one's goals. This conceptualization, which defines nonviolence as the absence of violence, suggests that violence is the 'norm' and nonviolence is 'not normal.' Indeed, while the relation between Islam and violence have been a theme of many studies, especially since the September 11 attacks, war as a means for selfdefense is hardly questioned. International norms, institutional and discursive continuities (such as the United Nations Charter, the Geneva Convention, etc.) enable the persistence of war and violence as a legitimate form of action under certain circumstances. However, "self-defense" is a loosely defined concept that is subject to manipulation in conflict situations. At times of war, quite often, parties attempt to justify terrorist attacks, collateral damages, preemptive strikes, and acts of revenge with the concept of self-defense. Yet, this weak support for nonviolence does not mean that nonviolent active resistance is ineffective to alter social structures that sustain

\footnotetext{
${ }^{36}$ For a complied edition on different religious traditions of nonviolence see Smith-Christopher, Daniel L., Subverting Hatred: The Challenge of Nonviolence in Religious Tradition (Cambridge, The Boston Research Center for the $21^{\text {st }}$ Century, 1998).

${ }^{37}$ Smith-Christopher, op. cit., 1998, 10.
} 
unjust practices or it is without merit. On the contrary, nonviolence is proactive strategy to fight injustice and history presents us numerous examples of success, such as the Civil Rights Movement of Martin Luther King Jr., Gandhi's nonviolent struggle against the British, among others.

\section{i. Defining Nonviolence}

Various definitions of nonviolence have been offered. ${ }^{38}$ Mohammed Abu Nimer defines nonviolence as "a set of attitudes, actions, or behaviors intended to persuade the other side to change its opinions, perceptions and actions", and pacifism as "the overall principles that guide the application of nonviolent strategies." ${ }^{39}$ In this sense, nonviolence means that the actors do not retaliate violently against their opponent, but absorb anger and damage as well as sending a message of patience and insistence in facing and correcting injustice. ${ }^{40}$ Martin Luther King Jr. identified the major principles of nonviolence as being physically non-aggressive, but spiritually dynamically aggressive; as not humiliating the opponent, but persuading the opponent and facilitating change through new understanding and awareness of moral shame to construct beloved communities; as directing its forces against the evil rather than against persons who are caught in these forces; as seeking to avoid both external physical and internal spiritual violence; and finally, as being based on the conviction that the universe is on the side of justice. ${ }^{41}$

${ }^{38}$ see Childress, James, Moral Responsibility in Conflicts: Essays on Nonviolence, War ad Conscience. (Baton Rouge, Louisiana State University Press: 1982); Jaggi, O. P., Religion, Practice, and the Science of Non-Violence. (New Delhi: Munshiran Manooharlal, 1974); Juergensmeyer, Mark, Fightng Fair: A Nonviolent Strategy for Resolving Everyday Conflicts (San Francisco: Harper and Row, 1986); Sharp, Gene, The Politics of Nonviolent Action, 3 vols. (Boston: P. Sargent, 1973); "Nonviolent Struggle", Journal of Palestine Studies vol. 17, No. 1, 1987; 37-55; King, Martin Luther, Jr., "Nonviolence and Racial Justice" in Christian Century, vol. 6, February 1957.

${ }^{39}$ Abu-Nimer, op. cit., 2003: 14.

${ }^{40}$ Ibid. .

${ }^{41}$ King, op. cit., 1957: 165-167. 
From the nonviolence perspective, peace is defined as a process in which human beings can establish foundations for interacting with each other and with nature in harmony and to institute just socialeconomic structures, where human beings can flourish and fulfill their potentials. This conceptualization of peace is based on the acknowledgment of dignity and worth of each and every human being, the recognition of the needs and interests of all those involved and addressing social, political and economic injustices. Therefore, "[n]onviolence implies an active commitment to social change that would ultimately result in a fair distribution of world resources, a more creative and democratic cooperation between peoples, and a common pursuit of those social, scientific, medical, and political achievements that serve to enhance the human enterprise and prevent warfare. ${ }^{, 42}$ In this process, employing nonviolent active resistance becomes crucial for building peace that can be sustained.

Nonviolence can be perceived as a way of life. It can be utilized as a strategy for social change, method of defense or liberation, or even resolving conflicts. Although it can be employed solely as an effective strategy, many of its supporters view nonviolence as a moral and ethical principle of action that aims to mobilize people at the grassroots level to demand justice. The underlying contention is that the means should be as ethical and just as the sought ends, if peace is to be enduring. Accordingly, its proponents argue that it is possible to radically transform all forms of direct, structural, and cultural violence and to establish a just social order through nonviolent action.

\section{ii. Assumptions of Nonviolence}

Traditions of nonviolence, including the Islamic tradition of nonviolence, share some common assumptions and understandings. First of all, they are based on the contention that violence breeds more violence and that legacy of violence renders the establishment of sustainable peace more difficult, if not impossible. Proponents of nonviolent resistance hold the premise that every individual is valuable in and of his/herself and has dignity and that should be

${ }^{42}$ Smith-Christopher, op. cit., 1998, 10. 
treated as such. In that respect, nonviolence seeks to avoid not only "external physical violence but also internal violence of the spirit."43 Therefore, from a nonviolence perspective, it is necessary to separate persons from the problem, the evildoer from the evil deeds. ${ }^{44}$ This way, nonviolent activists aim to focus on the sources of injustice and violence, yet by depersonalizing the conflict, they aim to build trust in the opponent. ${ }^{45}$ This view is supported by Childress, ${ }^{46}$ who argues that when the opponents realize that nonviolent activists will not harm them, they will feel more secure. This feeling of security will contribute to building trust between opponents and will eventually lead to more constructive relationships, including peace-building.

Another crucial aspect of nonviolent resistance is its assumption that the exercise of power depends on the consent of the ruled, who by withdrawing that consent can control or destroy the power of the opponent, thus challenging authority and hierarchy. ${ }^{47}$ Nonviolent action renders the violence of the opponent ineffective by withdrawing consent, submission, and rejecting retaliating violently. To do that nonviolent resisters employ various methods, which include symbolic acts such as vigils, marches, and prayers; acts of disobedience and non-cooperation such as boycotts and strikes; or nonviolent direct action such as hunger strikes, blockades, establishment of parallel institutions, among others. Nonviolent action can achieve significant social progress, when controlled and planned properly. Success of nonviolent action depends on the commitment and will of the people, a flexible but carefully developed strategy, good planning and organization, establishment of realizable objectives, and strict application of nonviolence.

\section{ISLAMIC APPROACHES TO WAR AND PEACE}

In order to evaluate the authenticity of Islamic nonviolence tradition, it is necessary to uncover how peace is defined according to

\footnotetext{
${ }^{43}$ Idem. .

${ }^{44}$ Ibid., 15.

${ }^{45}$ Idem. .

${ }^{46}$ Chidress, op. cit., 1982, 20.

${ }^{47}$ Said, op. cit., 1997.
} 
Islamic tradition. Islamic approaches to peace are based on the Quranic verses, the Hadith (sayings of Prophet Mohammed), and Sunna (deeds and examples of Prophet Mohammed). Since Quranic verses, Hadith, and Sunna refer to particular historical events, at times, they seem to contradict one another. Therefore it has not been possible to develop a single Islamic tradition of peace, and war. ${ }^{48}$ "Instead, there are a number of different traditions, each of which draws selectively on the Quran to establish legitimacy for its view of war and peace." 49

Contemporary Islamic approaches to war and peace can be categorized under three groups. The first one is the "offensive" Islamic approach to war and peace. ${ }^{50}$ This approach is based on the idea that Islam, as the only 'true path' to bring justice, freedom, and peace, should be the religion that governs the world and that Islam aims to expand its influence through various ways, including offensive wars. Adherents of this approach are convinced that the current economic, political, and international system that dominates the world only breeds oppression, injustice, and exploitation, therefore must be removed and replaced by God's governance. In order to achieve that goal, it is incumbent upon every Muslim to "fight" with whatever means they have. In this "jihad", according to adherents of this approach, offensive wars and even attacks on civilian targets are necessary evils to bring God's rule to earth.

\footnotetext{
${ }^{48}$ Kadayıfçı-Orellana, op. cit., 2002, 206.

${ }^{49}$ Tibi, Basam, "War and Peace in Islam" in The Ethics of War and Peace: Religious and Secular Perspectives Terry Nardin, eds. (New Jersey: Princeton University Press, Princeton, 1996), 129.

${ }^{50}$ See Kadayıfçı-Orellana, op. cit., 2002; Tibi, Bessam, Qutb, Sayyid, "War, Peace and Islamic Jihad" in Contemporary Debates in Islam: An Anthology of Modernist and Fundamentalist Thought, Mansoor Moaddel and Kamran Talattof, eds. (New York: St. Martin's Press, 2000), 223-245; al Banna, Hasan, Majmu'at Rasa'I al-Imam al-Shahid Hasan al-Banna new legal ed. (Cairo: Dar al Da'wa, 1990); al-Banna, Hasan, Five Tracts of Hasan alBanna (1906-1949),_Charles Wendell Jr., (Berkeley: University of California Press, 1978); Maududi, S. Abul A'la, Jihad in Islam (Lahore: Islamic Publications, 1980)
} 
The second Islamic approach to war and peace can be called "defensive" approach. ${ }^{51}$ Similar to the "just war" approach in the Western tradition, this approach is based on the belief that Islam permits use of violence under certain conditions, and the most obvious one of these circumstances is "self-defense." 52 Exponents of defensive Islam argue that in the face of oppression and persecution, Islam calls Muslims to defend themselves and to fight in order to establish justice and to restore harmony. Proponents of this approach can be further divided into two sub-categories, based on their approach regarding conducts of war (jus im bello). The first subgroup argues that not only the ends but also the means of war must be based on ethical grounds, and state that, although war is permissible, it is also limited. Those who uphold the defensive Islamic tradition call for a strict distinction between combatants and non-combatants, and prohibit killing of the innocent strongly.

The second subgroup, on the other hand, argues that although Islam permits war and violence under strict conditions, it also allows Muslims to adopt all means to win the war. In that line, they argue that killing of civilians may be necessary under certain circumstances. Islamic groups such as Hamas and Islamic Jihad, and supporters of these groups fall into this category. ${ }^{53}$

Finally, the third approach is the "nonviolent" Islamic approach to war and peace. Also based on the Quran, the Sunna and the Hadith,

\footnotetext{
${ }^{51}$ Idem.

${ }^{52}$ For more information, see, Kadayıfçı-Orellana, op. cit., 2002; Moulavi, Chiragh Ali, "War and Peace: Popular Jihad" in Moaddel and Talattof, eds., op. cit., 71-94, 72.; M.M., Qurashi, "The Concept of Islamic Jehad" in Islamic Thought and Scientific Creativity, Vol. 2, No. 1 (1991); Muhammad, Hamidullah, Muslim Conduct of State Lahore: Sh. Muhammad Ashraf, $3^{\text {rd }}$ ed. (1953); Sohail Hashimi, "Interpreting the Islamic Ethics of War and Peace" in Ethics of War and Peace: Religious and Secular Perspectives, Terry Nardin, eds. (Princeton: Princeton University Press, 1996); Malik, Iftikhar H. "Islamic Discourse on Jihad, War and Violence" in Journal of South Asian and Middle Eastern Studies, vol. 21, no. 4 (Summer, 1998), 47-78; Khan, Mohammed A. Muqtedar, "Peace and Change in the Islamic World" paper presented at the conference Islam and Peace in the 15/20 th Century, Washington DC. February, 1997.

${ }^{53}$ For more information see Kadayıfçı-Orellana, op. cit., 2002.
} 
this approach rests on the belief that nonviolent resistance is the preferred method for fighting injustice and resolving conflicts according to Islam. The next section will introduce the Islamic tradition of nonviolence and will provide examples of when and how it was employed.

\section{i. Critical Review of Existing Works on the Islamic Nonviolence Paradigm}

Adherents of nonviolence in Islam base their approach on the Quran, ${ }^{54}$ the Hadith and the Sunna of the Prophet, arguing that nonviolence is the preferred method. ${ }^{55}$ These Muslim scholars and activists argue that Islamic tradition incorporates different teachings and practices towards conflict and conflict resolution, and also a set of values that promote nonviolence. These values include, but are not limited to, justice ( $a d l$ ), helping the poor (ihsan), wisdom (hikmah), forgiveness (afu), and compassion (rahma) ${ }^{56}$ These scholars also add that if consistently and systematically applied, these values and practices can transcend all levels of conflict. Abu-Nimer, for example, argues that "uncovering and reconstructing nonviolent peace-building values and strategies will consciously assist in developing indigenous and local Muslim culture communities economically, socially, and politically. ${ }^{, 57}$ Thus, proponents of nonviolence paradigm within the Islamic tradition conclude that there is no theological reason for Muslims not to adopt nonviolence. In fact, not to adopt nonviolence is antithetical to Islam. ${ }^{58}$ Thus, it can be asserted that nonviolent paradigm is an authentic component of the Islamic peace discourse.

${ }^{54}$ Unless it is quoted from another source, citations from the Quran are from the version revised and edited by the Presidency of Islamic Researches IFTA, Call and Guidence, Saudi Arabia.

${ }^{55}$ Some of these scholars include Abdul Aziz Said, Mohammed Abu-Nimer, Chaiwat Satha-Anand, Jawdat Sa'id, Wahiduddin Khan, Eknath Easwaran, Douglas Karim Crow, Patout Burns, Rabia Terry Harris, Rober Johansen, and Khalid Kishtainy. Relevant works of these scholars will be cited in this article.

${ }^{56}$ Abu-Nimer, op. cit., 2003, 37.

${ }^{57}$ Abu Nimer, op. cit., 2003, 21.

${ }^{58}$ See Said, et. al., op. cit., 2001; Abu-Nimer, op. cit., 1996; Abu-Nimer, op. cit., 2003; Easwaran, Eknath, A Man to Match His Mountains: Badshah 
In order to understand the theological background of nonviolence in Islam, it is necessary to understand how peace is conceptualized in the Quran. Many references to peace (e.g., salam, silm, sulh) in Quranic discourse suggest that peace is a central theme in Islamic precepts. ${ }^{59}$ According to Quranic discourse, peace in Islam begins with God, since as-Salam (peace) is one of the Most Beautiful ninety-nine names of God: "Allah is He [...] the source of Peace (and perfection)" (Q59: 23). The Quran refers to peace as the greeting, language, and condition of Paradise (Q10: 10, 14:23, 19:61-63, 36:58). God calls believers to the "abode of peace" by stating in the Quran that "But Allah doth call to the Home of Peace: He doth guide whom He pleaseth to a way that is straight" (Q10: 25).

Various uses of the term "peace" in the Quran suggest that the Islamic concept of peace is wider than the absence of war. These uses recommend that peace is a positive state of safety or security, which includes being at peace with one-self, with fellow human beings, nature, and God. ${ }^{60}$ Based on these verses, Islamic scholars associate peace with a wide range of concepts. These concepts include, but are not limited to, justice and human development, wholeness, salvation, perfection and harmony. ${ }^{61}$ This understanding of peace is similar to

Khan: Nonviolent Soldier of Islam (California: Nilgiri Press, 1984); Kishtani, Khalid, Towards Nonviolence (Amman: Dar al Karmil, 1984); Terri-Harris, Rabia, "Nonviolence in Islam: The Alternative Community" in Daniel L. Smith-Christopher, eds., Subverting Hatred: The Challenge of Nonviolence in Religious Traditions. (Boston: Boston Research Center for the $21^{\text {st }}$ Century, 1998), 95-113; Sa'id, op. cit., 1993; Satha-Anand, Chaiwat, "Core Values for Peacemaking in Islam: The Prophet's Practice as Paradigm" in Elise Boulding, eds., Building Peace in the Middle East: Challenges for the States and Civil Society (Boulder Co: Lynne Reinner Publishers, 1993); Khan, Maulana Wahiduddin "Non-Violence and Islam", paper prepared for the symposium: Islam and Peace in the $21^{\text {st }}$ Century. Washington D.C. February 6-7, 1998.

${ }^{59}$ Kadayıfçı-Orellana, op. cit., 2002, 206.

${ }^{60}$ Idem. .

${ }^{61}$ Quran, footnote 2512 states: "Salam, translated "Peace", has a much wide signification. It includes (1) a sense of security and permanence, which is unknown to this life; (2) soundness, freedom from defects, perfection as in the word salim; (3) preservation, salvation, deliverance, as in the word 
the way peace is defined by the scholars of nonviolence in other religious and secular traditions.

Justice has been an integral aspect of the Islamic discourse of peace, since the Quran clearly states that the aim of religion is to bring justice. This is evident in Quranic verses such as: "We sent aforetime Our messengers with clear signs and sent down with them the Book and the Balance (of right and wrong), that men may stand forth in justice" (Q57: 25). Without justice, there can be no peace. Therefore justice is the essential component of peace according to the Quranic message. ${ }^{62}$ Furthermore, it is stated in the Quran that "O ye who believe! Stand firmly for justice as witnesses to Allah to even as against yourselves, your parents, your kin, and whether it be (against) the rich and poor... (Q4: 135); and “... to fair dealing, and let not the hatred of others to you make you swerve to wrong and depart from justice. Be just for it is next to peity..." (Q5: 8). Thus, the Islamic understanding of peace suggests that justice is the overriding principle and it must transcend any consideration of religion, animosity, race, or creed. Consequently, tyranny, which is a system that perpetuates injustice, is viewed as one of the greatest evils that must be removed. Although often mistranslated as "holy war" against external forces, jihad, which asks every Muslim to "strive in the cause of God," indeed asks Muslims to strive for justice. Based on the Quranic verse "We did raise among every people a Messenger (with a teaching): Worship God and Shun the Evil one" (Q16: 36), scholars, such as Jawdat Sa'id, argue that "the Prophets came with the message to avoid wicked tyranny and they disclosed that the tyrant could not continue to exist without our obedience to him." ${ }^{, 63}$ Similar to the modern understanding of nonviolence, this statement rests on the contention that people have the power to nonviolently resist tyranny and injustice, thus transform unjust structures by withdrawing consent. Thus, according to Sa'id, the message of the Prophets is "the sign of a tremendous nonviolent peaceful economic message."

sallama; (4) salutation, accord with those around us; (5) resignation, in the sense we are satisfied and not discontented; besides (6) the ordinary meaning of Peace, i.e. freedom from any jarring element. All these shades of meaning are implied in the word Islam.

${ }^{62}$ Ibid.

${ }^{63}$ Sa'id, op. cit., 1997, 5. 
It is clear, then, that peace, based on justice for all, is the central tenet of Islam. But how do we attain this peace according to Islam? Based on their reading of the Quran and the Hadith, proponents of the Islamic nonviolence approach hold that Islam seeks to attain peace through nonviolent means rather than violence, as it is believed to be the preferred way by God. In support of this view Jawdat Sa'id suggests the Hadith "whenever violence enters into something it disgraces it, and whenever, 'gentle-civility' enters into something it graces it. Truly, God bestows on account of gentle conduct what he does not bestow on account of violent conduct." ${ }^{64}$ Also, the Quranic verse "God commands you to treat (everyone) justly, generously and with kindness" (Q16: 90) is used to substantiate this stance.

Still, in the Quran, there are various verses that permit war as a legitimate conduct to correct injustice and overthrow tyranny and oppression. For example the Quran states:

Let those fight in the way of Allah who sell the little of this world for the other. Whose fighteth in the way of Allah, be he slain or be he victorious, on him shall we bestow a vast reward.

Those, who believe, do battle for the cause of Allah; and whose who disbelieve do battle for the cause of idol. So fight the minors of devil. Lo! The devil's strategy is every weak (Q4:74-74).

Based on verses such as these, various Islamic scholars argue that Islam cannot be a pacifist religion and that Islam permits fighting for self-defense. For instance, Sohail Hashimi argues that "Islamic discourse on war and peace begins from the a priori assumption that some types of war are permissible-- indeed required by God-- and that all other forms of violence are, therefore forbidden." ${ }^{, 65}$ Ifthikhar $\mathrm{H}$. Malik, quoting verses "And if they incline to peace, incline thou also to it, and trust in God" (Q8: 61) and "So do not falter, and invite for peace when you are the uppermost. And God is with you, he will not grudge (the reward) of your actions" (Q47: 35), recognize that the "Prophet would prefer peace over war and negotiation over confrontation and limited action over an outright plunder," but adds

\footnotetext{
${ }^{64}$ Idem. .

${ }^{65}$ Hashmi, op. cit., 1996, 151.
} 
that Islamic just war theory permits to defend Islamic lands when attacked. $^{66}$

However, a closer look at Quranic discourse indicates that "there is a clearly articulated preference in Islam for nonviolence over violence, and forgiveness (afu) over retribution." ${ }^{67}$ The verse, "the recompense of an injury the like thereof; but whosoever forgives and thereby brings about a reestablishment of harmony, his reward is with God; and God loves not the wrongdoers" (Q42: 40), advocates sincere forgiveness as the preferred option to establish God's harmony on earth. Hence, it is clear that the Islamic notion of peace suggests a condition of internal and external order, where peace is a responsibility of every Muslim, and the best way to attain that goal is through nonviolent means.

When articulating the Islamic perspective of nonviolence scholars agree on some major points. One such point is the sacredness of human life: i.e. the single origin of and equality among humankind. Sacredness of human life is stated clearly in the Quranic verse 5:32, which reads: "And if any one saved one life, it would be as if he saved the whole people." Thus destroying life (including one's own life) is strictly forbidden. Consequently, protecting human life and respecting human dignity is sacred in Islam. ${ }^{68}$

According to Islamic tradition, the individual's responsibility to uphold peace emerges out of the original constitution of human beings (fitrah), which is good and Muslim in character. ${ }^{69}$ Consequently, every human being is created in accordance with the form and image of God, as the Divine Names or Qualities are manifested in their entirety in the human form. ${ }^{70}$ Thus, each individual is a representative of God on earth (Khilafat Allah fi-l Ard Q2: 30) and responsible for the order thereof. This belief is based on the Quranic verse "Verily, we have honored every human being" (Q17: 70). It is also stated in the Quran that every human being is worthy of respect because $s / h e$ is

\footnotetext{
${ }^{66}$ Ifthikhar, op. cit., 1998, 59.

${ }^{67}$ Said, et. al., op. cit., 2001, 18.

${ }^{68}$ See Abu-Nimer, op. cit., 2003, 59-60.

${ }^{69}$ Said, et. al., op. cit., 2001, 7.

${ }^{70} \mathrm{Al}-$ Hakim, op. cit., 1998, 5.
} 
made "in the best of molds" (Q95: 4), and s/he possesses the faculty of reason, which distinguishes him/her from the rest of the creation (Q2: 30-34). According to the Quranic tradition, this faculty enables human beings to accept the "trust" of freedom of will, which no other creature is willing to accept (Q33: 72).

This quality of human form (fitrah) furnishes each individual with the prospect of being perfect (Insan-i kamil). It is a question of choice for the individual to strive in that direction. Human reason, or the individual's will, plays a crucial role in making this choice. Thus, the Islamic idea of fitrah suggests that the individual can choose to follow the path of God as his/her stewardess on earth to bring justice, harmony and peace, thus perfect his/her humanity, or can choose his/her ego (al-nafs) and follow their own interests. ${ }^{71}$ Within this context, "the greater jihad" (jihad al akbar) has always been the inner struggle to purify the self and behave in a manner which furthers rather then disrupts the divine harmony. ${ }^{72}$

Islamic scholars of nonviolence also agree that Islam incorporates several values and principles that constitute the basis of nonviolent action. For example, Kishtany identifies tolerance, persuasion, arguing, suffering, patience, civil disobedience and withdrawal of cooperation, rejecting injustice, strikes, emigration, boycotting, diplomacy, publicity, propaganda, and rituals like fasting, chanting and praying as some of such principles. ${ }^{73}$

In that respect, Maulana Wahiduddin Khan identifies patience $(s a b r)$ as one of the essential values that supports nonviolence. ${ }^{74}$ According to Wahiduddin Khan, patience is the focus of about 200 verses of the Quran and referred to indirectly in many others. ${ }^{75}$ Therefore, it is one of the core themes of the Scriptures. Patience ( $s a b r$ ), according to Wahiduddin Khan, makes a person capable of finding a positive and successful solution to a problem. ${ }^{76}$ Based on the

\footnotetext{
${ }^{71}$ Kadayıfçı-Orellana, op. cit., 2002, 208.

${ }^{72}$ Said, et. al., op. cit., 2001, 7.

${ }^{73}$ cited in Abu-Nimer, 2003, 43.

${ }^{74}$ Wahiduddin Khan, 1998, 1.

${ }^{75}$ Idem.

${ }^{76}$ Idem.
} 
verses such as "And endure patiently whatever may befall thee." (Q31: 17), he states that patience is set above all other Islamic virtues with the exceptional promise of reward beyond measure (Q39: 10).

Wahiduddin Khan furthermore, states that the entire spirit of the Quran is in consonance with the concept of patience. Patience, he states, implies a peaceful response or reaction, whereas impatience implies a violent response. He continues by adding that the word $s a b r$ expresses the notion of nonviolence, as it is understood in modern times. ${ }^{77}$ In this context, "jihad" refers to nonviolent activism, while "qital" is violent activism. He invokes the Quranic verse "perform jihad with this (i.e. the word of the Quran) most strenuously." (Q25: 52) to support this view. Because the Quran is not a sword or a gun, but a book of ideology, he concludes that performing jihad could only mean an ideological struggle to conquer peoples' hearts and minds through Islam's superior philosophy. ${ }^{78}$ Therefore, he reads this verse to support nonviolence.

Moreover, Wahududdin Khan argues that all of the greatest successes of Islam were achieved by nonviolent methods. His primary example is the Prophet's life. Wahiduddin Khan states that of the 23 year period of his prophethood, the initial 13 years, when Muhammed was in Mecca, the Prophet adopted nonviolence. ${ }^{79}$ Even, when Meccans waged war against Him, the Prophet chose to immigrate to Madina, which is a form of nonviolent activism. When the Meccan unilaterally waged war against Him, the battles of Badr and Uhud took place but the Prophet made a 10 year treaty called the Sulh alHudaybiyah, accepting all the conditions of his opponents. This peace treaty paved the way for peaceful, constructive activities.

Scholars of nonviolence also agree that although there are certain verses in the Quran that command qital (Q22: 39), they require crucial circumstances to be present. In that respect, Wahiduddin Khan states that aggression, launching an offensive war by the believers is totally forbidden. The Quran commands: "Fight for the sake of those that fight against you, but do not be aggressive (Q2: 190). Since

\footnotetext{
${ }^{77}$ Idem.

${ }^{78}$ Ibid., 2.

${ }^{79}$ Idem.. See also Terry Harris, op. cit., 1998.
} 
initiating hostility is not allowed in Islam, only certain defensive wars can be permitted: "when they attack you" (Q9: 13), he states that according to Quran there was one form of war which was time-bound strictly in retaliation to its purpose. This was to end fitna, since the Quran states: "Fight against them until fitna is no more" (Q2: 193). Wahiduddin Khan reads fitna to mean "that coercive system which had reached the extremes of religious persecution." ${ }^{80} \mathrm{He}$ also states that fitna refers to the ancient times when a political system dominated by coercion prevailed around the world, closing the doors to material and spiritual progress. Believers were urged to break this coercive system in order to usher freedom for material and spiritual progress.

Wahiduddin Khan also notes that there were only three real instances that Muslims entered a battle, referring to the Battles of Badr, Uhud, and Hunayn-- undertaken by the Prophet, when it became absolutely inevitable. He also states that these battles lasted only for half a day, each beginning from noon and ending with the setting of the sun. Therefore, it is possible to say that the Prophet had actively engaged in war for a total of a day and half, and observed the principle of nonviolence throughout his 23 year prophetic career. ${ }^{81}$

For Wahiduddin Khan the greatest problem of the Muslim world is that it has forgotten the Sunna of nonviolence and resorted to violence. This resulted in losing what had been gained before. The contemporary realities require a return to the principle nonviolence of the Prophet, to rejuvenate the Dawah, the peaceful struggle for the propagation of Islam. However, Muslims today, he observes, are easily provoked and become violent at anything against their way of thinking, or even not to their liking. ${ }^{82}$ Although not all Muslims are involved directly in violence, he states that according to Islam, keeping silent makes them indirectly responsible. He criticizes the modern ulema, intellectuals, and leaders of movements for adopting a violent narrative, and spreading this narrative among the young populations. This violent mentality, he argues, is responsible for having alienated them from their neighbors, and the only way for them to change this situation is to 'return' to nonviolence.

\footnotetext{
${ }^{80}$ Ibid., 5 .

${ }^{81}$ Ibid., 6.

${ }^{82}$ Ibid., 11 .
} 
One crucial obstacle in the minds of many Muslims is that peace does not guarantee them justice. However, Wahiduddin Khan states that peace does not automatically produce justice, but creates the possibility for establishing justice and gives the example of the Hudaybiyah treaty to illustrate that the Prophet made this peace not to exact justice, but to create opportunities. According to him, this treaty did give the Prophet the opportunity for dawah activities; after that, the Prophet not only ensured justice but also set Islam upon a much more solid footing. ${ }^{83}$

Jawdat Sa'id, on the other hand, compares wars to the cruel practice of offering human sacrifices to Gods, stating that "today we continue the tradition of offering human sacrifices with the victim's willing consent--when we push people to go to war in the name of holy patriotism and heroism." ${ }^{84} \mathrm{He}$ adds: "we still have not understood that such a thing has changed into a mere sacrifice devoid of holiness or act of heroism." ${ }^{85}$ Sa'id also asserts that armies and governments have lost their traditional role in protecting the populace; while people have resorted their role in protecting themselves. ${ }^{86}$ According to Sa'id, war neither solves the problem, nor even bring the needed ease of conscience. Referring to Quranic verse, "God does not change the condition of a people until they change what is within themselves," he states that "as soon as we cease to place our trust in a Napoleon or a Hitler to make peace and unity, and as soon as we trust in ourselves being able to change what is within ourselves," we will be able to establish peace. $^{87}$

In this sense, the "sacred struggle," jihad, cannot mean violence and aggression. Sa'id backs this view with the following verses:

God forbids you not respecting those who have not fought against you on account of your religion, and who have not driven you out from

\footnotetext{
${ }^{83}$ Ibid., 13.

${ }^{84}$ Sa'id, Jawdat, op. cit., 1997, 3.

${ }^{85}$ Idem. .

${ }^{86}$ Ibid., 4.

${ }^{87}$ Idem. .
} 
your homes, that you be kind to them and deal equitably with them (Q60: 8), and

If they withdraw from you but fight you not, and (instead) send you (guarantees of) peace, then Allah hath opened no way for you (to war against them) (Q4: 90).

Based on these verses, Sa'id states that the true message of Islam is nonviolence. Said supports his position with a Hadith transmitted by the Prophet's companion Sa'd Ibn Abi Waqqas. ${ }^{88}$ According to this Hadith, the Prophet was asked by his companion Abu Dharr al-Ghifari what to do if attacked. Prophet is recorded to have replied: "stay in your house." When Abu Dharr asked: "but what if someone entered into my home (to kill me)," the Prophet replied: "if you fear to look upon the gleam of the sword (raised to strike you), then cover your face with your robe- this will he bear the sin of killing you as well as his own sin." ${ }^{\text {" } 9}$ This, according to Sa'id, clearly indicates that violence is shunned and nonviolence is preferred in Islam. Furthermore Sa'id refers to the Prophet's Hadith which states "whoever takes life by the sword, by the sword shall he perish" as another proof that nonviolence is the preferred method. ${ }^{90}$

In support of his stance Sa'id also reminds us the story of Adam's sons Abel and Cain stated in the Quran, which, according to Sa'id clearly illustrates God's preference for nonviolence. ${ }^{91}$ The story narrates that, Cain, jealous of his brother Abel, attempted to kill his brother Abel, because Abel's sacrifice was accepted by God and not his. But when he attempted to kill Abel, Abel tells him "if you stretch your hand to slay me, it is not me to stretch my hand against you to slay you for I fear Allah (...)" (Q2: 28). The Quran goes on to say that "if any one slew a person unless it be for Murder or for spreading Mischief in the land, it would be as if he slew the whole people. And if anyone saved a life it would be as if he saved the life of the whole people" (Q2: 32). Hence, Sa'id concludes that Islam's message is Kun ka Ibn Adam (Be like the son of Adam).

\footnotetext{
${ }^{88}$ See ibid., 4.

${ }^{89}$ Cited in Idem. .

${ }^{90}$ Idem. .

${ }^{91}$ Sa'id Jawdat, op. cit., 1993; see also Abu-Nimer, op. cit., 2003, 44.
} 
In agreement with Wahiduddin Khan, Sa'id emphasizes that patience is the key to nonviolence in Islam since the Quran has all the Prophets speak: "And we shall surely bear with patience all the harm you do us." (Q14: 12-13). ${ }^{92}$ For that reason, he states that "it is obligatory upon us- people of understanding- and it is within our grasp, to continually maintain nonviolent peaceful contacts with other understanding people in the world, without waiting for the politicians." 93

Islamic scholars of nonviolence also agree that there is also a clear preference for forgiveness in Islam, especially when one repents. ${ }^{94}$ According to Sa'id, the notion of forgiveness is the basis of nonviolence in Islam. Building his argument on this basis, he insists that violence is illegitimate and forgiveness is the norm. To support his position, he refers to a famous Hadith that states:

Whenever violence enters into something it disgraces it, whenever 'gentle-civility' enters something it graces it. Truly God bestows on account of gentle conduct what he does not bestow on account of violent conduct $^{95}$

Based on the same Hadith, Abdul Ghaffar Khan, ${ }^{96}$ during his nonviolent struggle against the British, stated that God grants to rifq (gentleness) what he does not grant to unf (violence). ${ }^{97}$ Furthermore, he argued that the word rifq has been used in this Hadith as an antithesis to unf (which means violence). From here, he also argued that these terms convey exactly what violence and nonviolence mean in present times. According to Ghaffar Khan, this Hadith clearly indicates the superiority of the non-violent method and adds that God does not love fasad, which is another word for violence. Based on the Quranic verse (2:205): "[w]hen he turns his back, his aim everywhere is to spread mischief through the earth and destroy crops and progeny but Allah loveth not mischief," he understands fasad to mean

\footnotetext{
${ }^{92}$ Idem.

${ }^{93}$ Ibid., 8.

${ }^{94}$ Kadayıfçı-Orellana, op. cit., 2002, 263.

${ }^{95}$ Cited in Abu-Nimer, op. cit., 2003, 43.

${ }^{96}$ See below.

${ }^{97}$ Johansen, op. cit., 1997; see also Kadayıfçı-Orellana, op. cit., 2002, 264.
} 
'mischief.' Here, fasad is that action which results in disruption of the social system, causing huge losses in terms of lives and property. Thus, Ghaffar Khan concludes that God loves non-violence and abhors violent activity in human society.

Another important aspect of nonviolence in Islam is the concept of power. According to Rabia Terri Harris, power in Islamic understanding of nonviolence accumulates to people through the unarmed struggle and continues to reside there. ${ }^{98}$ Armed struggle is only a branch, which dies if torn from its root- for it is only unarmed struggle that teaches reliance on God. ${ }^{99}$ This is based on the assumption that power in its essence is non-coercive, but consensual. It is only dissipated, never generated through coercion. Sa'id, for example, states that responding to violence with violence is to actually empower the position of the violent person. ${ }^{100}$ By withdrawing consent, people render power and tyranny ineffective. Observed from this point of view, power, from the perspective of the Islamic tradition of nonviolence, becomes an infinite spiritual resource, which infuses into those who abandon their own objectives for the objectives of their Creator. ${ }^{101}$

Islamic scholars of nonviolence also hold that the historical period has changed and new technology has introduced weapons that cannot distinguish between the combatants and non-combatants. Scholars like Chaiwat Satha-Anand, Sa'id, and Wahiduddin Khan assert that killing of non-combatants is clearly against the Islamic jus im bello, therefore violence cannot be permissible. Hence Muslims should adopt nonviolence. In support of this argument Jawdat Sa'id states:

What is in the order of the world is that it has reached an extent that world problems can no longer be solved by violence (bi-l- 'unf). The evidence for this that the great powers themselves cannot use violence anymore to solve their conflicts. As for the weak and the oppressed (al-mustad 'afun) among small states, their violence will only turn in

\footnotetext{
${ }^{98}$ Terri Harris Rabia, op. cit., 1998,108.

${ }^{99}$ Idem. .

${ }^{100}$ Sa'id, op. cit., 1997, 6.

${ }^{101}$ See idem. .
} 
favor of the great powers whenever they attempt to solve their problems by such means.

With the advent of the nuclear bomb, nonviolence has become an historical destiny- not just a choice as it was before. Those who do not accept this as true will only expose themselves to repeated suffering and losses. History does not change its course, people are the ones who adopt to it. ${ }^{102}$

The adherents of nonviolence also state that the use of violence as a means to address conflict was a minor element in the life of the Prophet and in the Scripture, and therefore, it should not occupy as much attention today. ${ }^{103}$ Islamic history, the Prophet's tradition, and the Scripture itself are rich sources for developing nonviolent strategies to deal with current social and political problems. In order to justify their claims of nonviolence, these scholars and activists refer to Quranic verses such as:

Whenever they kindle the fire of war, God extinguishes. They strive to create disorder on earth and God loves not those who create disorder (Q5:64);

God commands you to treat (everyone) justly, generously and with kindness (Q16:90);

Repel evil (not with evil) but something that is better (Ahsan) -that is with forgiveness and amnesty (Q13: 22). ${ }^{104}$

Based on the Sunna of the Prophet, Chaiwat Satha Anand argues that jihad aims to end "structural violence," but the means used are not independent of moral scrutiny. ${ }^{105}$ On the basis of Quran and Sunna, he states that Islam forbids killing noncombatants and refers to the Hadith: "Go in God's name trusting in God, and adhering to the religion of God's messenger. Do not kill a decrepit old man, or a young infant, or a woman: do not be dishonest about booty, but collect

\footnotetext{
${ }^{102}$ Ibid., 1.

${ }^{103}$ Abu-Nimer, op. cit., 2003, 40.

${ }^{104}$ Kadayıfçı-Orellana, op. cit., 2002, 256.

${ }^{105}$ Satha- Anand, Chaiwat in Said, et. al., op. cit., 2001, 198.
} 
your spoils, do right and act well, for God loves who do well." 106 These rules of engagement are also clearly put down by the first Caliph. Before a battle, the first Caliph is recorded to have said:

Stop, O, people, that I may give you ten rules for your guidance in the battlefield. Do not commit treachery or deviate from the right path. You must not mutilate dead bodies. Neither kill a child, or a women, or an aged man. Bring no harm to the trees, nor burn them with fire, especially those, which are fruitful. Slay not the enemy's flock, save for your food. You are likely to pass people who have devoted their lives to monastic services, leave them alone. ${ }^{107}$

Based on these strict Islamic rules of conduct Satha-Anand asserts that modern warfare, which cannot distinguish between combatants and noncombatants, and which includes weapons of mass destruction, is not permitted according to Islam. ${ }^{108}$ Inamullah Khan supports this view and states that although at a minimal level Islam permits war, conduct of war must be as humane as possible. ${ }^{109}$

Subsequently, Satha-Anand articulates eight theses on Muslim nonviolent action that are rooted in the original vision of Islam and 'true' meaning of peace thereof. ${ }^{110}$ The first thesis is that the problem of violence is an integral part of the Islamic moral sphere. Violence, if used by Muslims, must be governed by the rules prescribed in the Quran and the Hadith. If violence cannot discriminate between combatants and noncombatants, it is not acceptable according to Islam. Modern technology of destruction renders discrimination virtually impossible. Therefore Muslims cannot use violence in the modern world. Islam teaches Muslims to fight for justice with the understanding that human life --as is all God's creation-- has a purpose and is sacred. For that reason to be true to Islam requires Muslims to utilize nonviolent action as the mode of struggle. ${ }^{11}$

\footnotetext{
${ }^{106}$ Idem. .

${ }^{107}$ Ibid., 199.

${ }^{108}$ Ibid., 201-202.

${ }^{109}$ See Khan, Inamullah, op. cit., 1985, 9-11.

${ }^{110}$ Satha-Anand in Said, et.al., op. cit., 2001, 209.

${ }^{111}$ Idem. .
} 
Moreover, Satha-Anand argues that Islam itself is a fertile soil for nonviolence because of its potential for disobedience, strong discipline, sharing and social responsibility, perseverance, selfsacrifice, the belief in the unity of the Muslim community, and the oneness of mankind. ${ }^{112}$ Accordingly, Satha-Anand suggests that principles of nonviolence in Islam are derived from the five pillars of Islam. These include to obey God and his Prophet only and disobey the others if necessary; practice discipline through prayers; solidarity and support of the poor through zakat; self sacrifice, suffering and patience through fasting; unity and brotherhood through pilgrimage. ${ }^{113}$ These pillars also become the basis to undertake nonviolent acts of resistance such as civil disobedience, vigils, protests, refusal to pay taxes, among others.

Other scholars, such as Johansen, Crow, Grant, and Ibrahim, ${ }^{114}$ also identify various Islamic rituals and traditions as effective sources of nonviolent action in Islam. These include "fasting rituals, which are excellent training for hunger strikes; ritualistic prayers, for the habituated formation of worshipers into parallel lines to prepare people for engagement in disciplined actions; religious chanting, which can become an outlet for peaceful marches, meetings and sitins." 115 These traditions and rituals are in line with nonviolent action strategies employed in various movements around the globe. Values, beliefs, rituals and practices presented here indicate that Islamic tradition not only incorporates vast resources for mobilizing the population toward nonviolent action, but also suggest that Islam privileges nonviolent action to resolve conflicts and to remove unjust social, political and economic structures with just ones.

\section{ii. Islamic Tradition of Nonviolence in Practice}

Nonviolence in Islam is neither a theoretical exercise to "feelgood," nor is it a modern hermeneutical extrapolation into a distant

\footnotetext{
${ }^{112}$ Ibid., 209.

${ }^{113}$ Satha-Anand, op. cit., 1993.

${ }^{114}$ Crow, Ralph, Philip Grant, and Saad Eddin Ibrahim, eds., Arab Nonviolent Struggle in the Middle East, (Boulder: Lynne Rienner, 1990).

${ }^{115}$ See Abu-Nimer, op. cit., 2003, 83.
} 
historical past. On the contrary, nonviolent interpretations of Islam base their approach on the Quran, the Hadith, and the Sunna, and there are various examples of significant and successful nonviolent movements that took place in both pre-modern and modern history. ${ }^{116}$ Among these examples, the nonviolent movement of Pashtuns, led by Ghaffar Khan during the British colonial period in India, is telling. ${ }^{117}$ This example is in striking contrast to the current situation in Afghanistan, since Pashtuns are one of the major ethnic groups in this country. Considering the rise of Taliban and their violent interpretation of Islam in Afghanistan, and among Pashtuns in particular, the example of Ghaffar Khan becomes even more interesting of a case study.

Living in the North-West Frontier Province of British India, Pashtuns had the reputation of being extremely aggressive and violent. ${ }^{118}$ Their cultural norms emphasized vengeance and military arts. Johansen states that:

"In selecting a case of nonviolent action from this cultural context, one is examining a difficult case in which the people and culture seemed unusually violent, in order to demonstrate that a militant group, displaying what today would be called "fundamentalist" tendencies bearing the fervor of religious nationalism (although led by a rare traditional leader), developed nonviolent strategies, pursued by a wide following, and achieved notable success." 119

However, it is from this context that Ghaffar Khan was able to articulate a nonviolent resistance movement to repel the British.

\footnotetext{
${ }^{116}$ Some of the recent nonviolent movements are the mass protest against the British in 1919, Palestinian strike of 1936, 1948 Iraqi uprising, Sudanese insurrection of 1985. For more information and other examples, see Crow, et al., op. cit., 1990; Harris, op. cit., 1998; and Abu-Nimer, op. cit., 2003.

${ }^{117}$ This movement dissolved after the establishment of Pakistan (Ghaffar Khan was opposed to separation of Pakistan as a distinct state and believed that Hindus and Muslims should stay together and coexist peacefully), and many of its member became citizens of Pakistan, although some remained in India.

${ }^{118}$ See Johansen, op. cit., 1997.

${ }^{119}$ Ibid., 57.
} 
Ghaffar Khan, as a son of a religious chieftain, felt the personal religious calling to Serve God by uplifting his people through social reform and education. Ghaffar Khan was convinced that pervasive violence was responsible for the Pashtun society's inability to uplift itself. ${ }^{120}$ Therefore he decided to create a nonviolent organization to bring social, economic, and political reforms. Based on this commitment, he established a nonviolent army, called Khudai Khidmatgars (servants of God), founded on Islamic principles. Consistent with the code of honor in the Pashtun society and Muslims beliefs, those who joined this army declared that they were willing to swear before God to give their lives for their people.

Ghaffar Khan's army (which also included women) was drilled and disciplined with officers, cadres, uniforms, a flag, a drum and bagpipe corps. However, this army was completely nonviolent, and Khan told his followers that he was going to give them the most powerful weapon, the weapon of the Prophet, and this weapon was "patience" and "righteousness." In his own words, Khan stated:

I am going to give you such a weapon that the police and the army will not be able to stand against it. It is the weapon of the Prophet, but you are not aware of it. That weapon is patience and righteousness. No power on earth can stand against it... when you go back to your villages, tell your brethren that there is an army of God, and its weapon is patience. Ask your brethren to join the army of God. Endure all hardships. If you exercise patience, victory will be yours. ${ }^{121}$

The basic teachings of this army were forgiveness, sacrifice, and nonviolence. Ghaffar Khan's interpretation extended the notion of $s a b r$ (patience) to mean renunciation of all forms of violence, thus became a key element in his religious teaching and practice. Joining the army required an oath to refrain from violence and from taking revenge, as well as to refrain from any antisocial customs and practices, and to devote at least two hours a day to social work. This oath was of great importance because Pashtun culture assumed that one's word could not be broken without losing one's integrity. The word must be honored with life.

\footnotetext{
${ }^{120}$ Ibid., 58.

${ }^{121}$ Cited in idem. .
} 
Looking at the Ghaffar Khan's example, Johansen concludes that "Muslim religious teaching and discourse provided a basis for enabling people to contest the meaning of their own tradition in contemporary life," and "[c]ommitment to Islam "sustained the determination and courage if the leadership of the Khudai Khidmatgars movement." 122 As this case proves, faith not only created space within the minds of Muslims for employing nonviolence, but also reduced the moral space within which they considered violence to be legitimate.

Ghaffar Khan's example might strike readers as unique and unprecedented in the light of current representations of Islam. However, it is not the only example. Islamic history is rich in such examples, and men were not the only figures who were successful in resolving conflicts nonviolently. One of the important women figures concerning Islam and nonviolence is Lala Aziza from Morocco, who lived during the $14^{\text {th }}$ century. ${ }^{123}$ According to the travel accounts of a religious scholar called Ibn Qunfudh, who met her in 1362, she had successfully reconciled a conflict between two groups peacefully. According to Ibn Qunfudh, al-Hinti, the governor of Marrakesh and the most powerful general in Morocco at the time, was engaged in a battle to conquer all of southern Morocco. ${ }^{124}$ His violence and aggression was well known to the inhabitants of the region. With his 6,000 men, he came to Seksawa where Lala Aziza was living.

It was Aziza who met them near the mountains. Standing alone before the army and the general, she confronted them with her words and with his own faith. She spoke of the demands of the Creator on justice, the pull of the good, and wrong of harming God's creation. ${ }^{125}$ According to the accounts of the general, as recorded by Ibn Qunfudh, she answered him before he could ask anything. ${ }^{126}$ "She knew what was going on inside of him, his ideas, the way he was thinking, and he

\footnotetext{
${ }^{122}$ Johansen, op. cit., 1997, 66-67. Emphasis in the original.

${ }^{123}$ See Combs-Schilling, op. cit., 1994.

${ }^{124}$ Idem. .

${ }^{125}$ Idem. .

${ }^{126}$ Ibid., 17.
} 
was unable to respond to her or to reject her requests." ${ }^{127}$ With her words and argumentation, she was able to talk him out of the conquest. She also convinced him to leave the people unharmed. Her story has been told over the centuries as the "story of a woman who dared to stand up to a general and his army." Her legacy has been an inspiration of the people of the region since then. During the colonial era, her sanctuary played an important role against oppression and violence. It is recorded that eight men fled to her sanctuary when the colonial army conscripted them. ${ }^{128}$ They were protected and the French official agreed to let them go.

These two examples of nonviolent action based on Islamic principles challenge the oversimplified caricaturization of Islam as a religion of violence that cannot incorporate nonviolence. Systems of belief and action are not constant, but change as people contest their meaning. These examples also suggest that if the religious values are sensitively understood and implemented, they can contribute to peace, nonviolence, and coexistence. As Johansen also observes, every religious generation reconstructs its religious tradition to fit its perceptions of contemporary conditions. ${ }^{129}$

\section{CONCLUSION}

Today, religion is viewed as one of the major propellants and perpetuators of violent conflict, and Islam, in particular, is often associated with violence and terrorism in the minds of many. Indeed, as Samuel Huntington observed, "in the modern world, religion is a central, perhaps the central force that motivates and mobilizes people." ${ }^{130}$

However, every major religious tradition has peace as its primary goal and claim that the implementation of its precepts will result in peace. Each major religious tradition incorporates values like

\footnotetext{
${ }^{127}$ Idem.

${ }^{128}$ Idem. .

${ }^{129}$ Johansen, op. cit., 1997, 55.

${ }^{130}$ Huntinton, Samuel, "If Not Civilization, What?" in Foreign Affairs, vol. 72, No. 5 (November-December, 1993) 186-194, 192.
} 
security, harmony, justice and human dignity and also has a repertoire of practices and precepts for resolving conflicts and establishing a just and peaceful system. Hence, religion can also be (in fact has been) a rich source for peace-building, conflict resolution and nonviolent resistance.

Like followers of other religious traditions, Muslims share a common calling to work for peace. In the case of Muslims, the calling is rooted in the Holy Quran, which enjoins humanity to "strive as in a race in all virtues" (Q5:48). ${ }^{131}$ What, then, is the best path to pursue to achieve the Islamic ideal of peace and harmony?

Basing their claims on the Quran, the Hadith and the Sunna, various Muslim scholars and activists have offered different paths. These include offensive, defensive and nonviolent approaches. This article particularly focused on the nonviolence approach, and argued that nonviolence as a means of affecting change and resolving conflict is an authentic mechanism rooted in the Islamic tradition. Yet, Islamic tradition of nonviolence is an understudied and under-explored field of research. Even the majority of Muslims contend that Islam allows violence under certain circumstances, and that in the Islamic discourse there is no room for nonviolent approaches.

There are various explanations for existence of multiple interpretations of a single religious tradition. Every religious scripture is communicated through words and has to go through human interpretation. The meaning of words may change over time, new developments may require new concepts and new words, which are not in the scriptures. Therefore, although one might believe that God revealed guidelines to humanity, one must also realize that God's message can only be communicated through words and symbols that are subject to human interpretation, in the face of ever-changing conditions.

Contemporary interpretation of Islamic approaches to peace has been greatly influenced by the turbulent social, political and economical events of the $20^{\text {th }}$ century that took place in the Muslim

\footnotetext{
${ }^{131}$ Said, Abdul Aziz, Nathan C. Funk, and Ayşe S. Kadayıfçı, op. cit., 2002,
} 2 . 
world. Islamic history during this period has been one of decline in every aspect of life. This has caused great frustration among the Muslims and contributed to the spread of violence and selective reading of the sacred texts to justify violent acts. Indeed, the increase of violence among the Muslim communities is alarming. It is, then, crucial for Muslims to realize that they have a duty and responsibility to reflect on their belief systems, contribute maximally to understanding the meaning of life, to implement the highest values of their religion. Although it is important to understand the reasons behind rise of violence among Muslims today, it is also necessary to employ strategies to empower those Muslim groups who are working to bring peace through nonviolent means. In that respect, Muslim theologians, scholars, and activists should recover the Islamic tradition of nonviolence and explore ways in which it can be applied meaningfully to resolve conflicts and restore justice and harmony. 